\title{
Expanding the Federation? The Ongoing Process of Devolution in the Yukon Territory
}

\section{Adam P MacDonald}

\section{Royal Military College of Canada}

\begin{abstract}
Since the 1970s, the transition of jurisdictional authority, specifically resource management, from the federal government to the Yukon Territorial Government (YTG) has been an ongoing endeavor. To date the transfer of powers from Ottawa has been well absorbed by Whitehorse, which has developed the institutions and expertise needed to accept these new areas of responsibilities. While it appears unlikely that this process will result in provincehood due to an apathetic Yukon political culture regarding this matter and Ottawa's unwillingness to reopen the Constitution, further devolution of powers, via federal statue, to Whitehorse in the future is expected. Devolution, however, in the Yukon is a dual process involving not just the federal government and YTG, but the Yukon First Nations as well. Aboriginal self-rule is a far more complex issue, with concerns over the lack of an experienced labour force and the cumbersome relationship with Whitehorse characterized by funding and decision-making process disputes. Ultimately, the level of autonomy and self-rule achieved by the Yukon First Nations will be dependent on their ability to secure immediate influxes in financial and technical assistance from both Ottawa and Whitehorse. This condition, however, is contingent upon the acceptance of the federal government and YTG of the Yukon Fist Nations as a legitimate level of government and, therefore, an increased willingness to develop strategies to address immediate concerns.
\end{abstract}


The northern territories are vestiges of Canada's colonial past. They are not autonomous political entities like the provinces but are creatures of federal statues in which ultimate power resides in Ottawa. The process of devolution, however, is an ongoing endeavor aimed at transferring powers from the federal government to their territorial counterparts. Of the three territories, the Yukon is the most advanced in this respect. To date the transfer of powers from Ottawa has been well absorbed by the Yukon Territorial Government (YTG), which has developed the institutions and expertise needed to accept these new areas of jurisdictions. Devolution, however, in the Yukon is a dual process involving not just the federal government and YTG, but the Yukon First Nations as well. Aboriginal self-rule is a far more complex issue, with concerns over the lack of an experienced labour force and the cumbersome relationship with Whitehorse characterized by funding and decision-making process disputes. Devolution in the Yukon, therefore, is increasingly concerned with the issue of Aboriginal self-rule since many in the YTG believe the Yukon First Nations have not reached a sufficient stage of institutional development to effectively be an autonomous level of government. The likelihood of the Yukon Territory becoming a province via constitutional reform is minimal considering the general apathetic Yukon political culture towards the issue and the federal government's unwillingness to reopen the Constitution. The Yukon, however, may affect the future devolution processes occurring in the other territories, specifically with regards to Aboriginal self-government.

\section{$\underline{\text { Devolution as a Model of Political Development }}$}

Gurtson Dacks' model of political development and devolution highlights the interdependent relationship which exists between them. Dacks's model is a three dimensional construct, analyzing devolution as a function of 1) civic development, 2) institutional development, and 3) constitutional development. Though not necessarily linear in nature, there is a normative assessment of how each level of political development affects one another in the devolution process. His model provides a methodology for the study of the disparities that exists between the devolution processes of the YTG and the Yukon First Nations (1).

\section{$\underline{\text { Civic Development }}$}

Civic development is concerned about the creation of a political culture articulating a desire for devolution. The development of such a political culture is based on the societal consensus of identification as a group and the need for self-government to address the needs of their community. Within this political culture, an active civil society shall be developed in which a civic elite will emerge, mobilizing and organizing the society while leading the devolution process.

\section{$\underline{\text { Institutional Development }}$}

The creation of effective government institutions and procedures, such as representation and accountability, which are supported by the society, is essential for establishing the 
infrastructure needed for self-rule. The development of an institutional elite, having the specific expertise to implement new areas of authority, is also a crucial factor. Institutional development is aimed at establishing an organization with the skill assets and resources needed to present an alternative form of government, legitimizing claims for greater autonomy.

\section{Constitutional Development}

Dacks argues that constitutional entrenchment of the devolution process is heavily dependent on the levels of civic and institutional development. If there is a strong political culture for self-rule combined with the political infrastructure to assume the responsibilities of a previous government, the likelihood of constitutional development is high. Defining the status of a region constitutionally, however, may create new powers or simply entrench those previously granted through other forms of legislation.

\section{The History of Devolution in the Yukon Territory}

Before beginning an analysis into the current stage of political development with respect to devolution in the Yukon, a short history of this process is needed to provide a context for its contemporary study. Indeed, many of the issues affecting the present state of devolution are products of past political actions. By investigating this history, therefore, the roots of such concerns can be analyzed, resulting in a predictive capability in forecasting the future avenue(s) of the devolution process.

Following the Gold Rush in the late 19th Century, the Yukon Territory was created in 1898 via the Yukon Act(2). The territory was governed by a Commissioner, a federal appointee, whom had an executive council advising him/her. Though the committee gradually became to be exclusively comprised of elected officials, executive power remained solely with the federal appointed Commissioner who was in charge of the dayto-day governance of the territory. The Commissioner was responsible not to the people of the Yukon but the federal government through the Minister of the Department of Indian Affairs and Northern Development (DIAND). Letters of Instruction were the legislation employed by DIAND to relay the federal government's intent with respect to matters pertaining to the Yukon to the Commissioner, who was legally bound to abide by them(3).

By the 1970s, a vocal political elite in the Yukon Territory arguing for a greater role in the decision-making process for elected officials emerged. Though constituting a majority of the Executive Committee, elected representatives had no official function in the government process which was dominated exclusively by the Commissioner; the extent of the Commissioner's powers were seen as undemocratic and colonial in nature. In 1978, the first ever territorial election contested by political parties gave the Yukon a party-based government with a leader equivalent to that of a premier in the provinces(4). 
Devolution had been a major campaign issue in the territorial election and following Joe Clark's victory in 1979 at the federal level, the Conservatives, which supported devolution in the Yukon, moved quickly to remove the Commissioner from the decisionmaking process. On 9 October 1979, then Minister of DIAND, Jake Epp, sent a Letter of Instruction to Commissioner Christensen stating "You will not be a member of the cabinet or the Executive Council, and will not participate on a day-to-day basis in the affairs of the Cabinet or the Executive Council"(5). Though the move created initial political turmoil, resulting in the resignation of the Commissioner Christensen, the role of the Commissioner had essentially become the equivalent of a provincial LieutenantGovernor, fully accepting the advice of the premier who was the head of government. By removing the Commissioner from the Executive Council, also, the Legislative Assembly became the institution responsible for the creation and implementation of the territorial budget, giving the elected government legitimacy as the real organization of power(6). These new found powers introduced the concept of responsible and representative government into the territory by connecting the government, which had essentially inherited the former powers of the Commissioner, to the populace through elections.

The new political arrangement became entrenched in the amended Yukon Act of 2002 which states in the preamble "Whereas Yukon is a territory that has a system of responsible government that is similar in principle to that of Canada"(7) [emphasis added]. Though the Commissioner retains executive power, it is the elected government, the responsible government that has the actual political power. Responsible government is supported by Article 10 which states the Executive Council, the decisionmaking body in the Yukon, shall comprise only of the elected members of the Legislative Assembly(8). Furthermore, Article 4 (3) limits the ability of the Commissioner to intervene in the decision-making process by forcing him/her to act in accordance with any written instruction given either by the Governor in Council (the Premier of the Yukon) or the Minister of DIAND. The position of the Commissioner, therefore, retains its executive functions but is obligated to act in accordance with the wishes of the elected government.

After de facto political power had been transferred from the Commissioner to the elected government, the next phase of devolution consisted of transferring federal areas of jurisdictions, administered by DIAND, to the YTG. One of the first major agreements was the Yukon Oil and Gas Accord (YOGA) which came into effect in 1998. YOGA established the process of transition of the administrative control of the Yukon's oil and gas industries to the YTG(9). All other resource control was handed to the YTG following the implementation of the amended Yukon Act (2002).

Discussions concerning amending the Yukon Act began in the mid-nineties culminating in the Devolution Protocol Accord signed in September 1998 by the federal government, the YTG, and the Yukon First Nations. Control over public lands, forests, minerals and to a certain degree water were transferred from DIAND to the Yukon Commissioner, though there was an understanding that actual control of these resources would be the responsibility of the Cabinet of the YTG. This transfer of powers discussed in the 
Protocol became legal in 2002 with the amending of the Yukon Act. To date, the Yukon is the only territory in Canada with a resource revenue sharing agreement with the federal government (10).

At the same time that devolution was developing at a territorial level, the Yukon First Nations were, also, heavily engaged in discussions concerning self-government with DIAND and the YTG. The major Aboriginal organization in the process was, and still is, the Council of Yukon First Nations (CYFN) which represents 11 of the 14 Yukon First Nations(11). Talks between the three accelerated during the 1970s but a real breakthrough did not germinate until the signing of the Umbrella Final Agreement (UFA) in 1993. The UFA laid the groundwork for further negotiations in which each of the First Nations would construct a final land claim agreement with the federal government and the YTG(12). The UFA, also, allocated almost $10 \%$ of the Yukon's land base under the jurisdiction of the CYFN, which was in charge of resource management and land use planning in this area(13). Another major aspect of the agreement was the creation of a royalty regime concerning natural resources, established between the CYFN and the YTG stating the CYFN would receive $50 \%$ of the royalties up to a cap of $\$ 2$ million in which case afterwards they were entitled to $10 \%(14)$.

To address these growing areas of responsibilities, the CFYN has created various Lands and Resource Departments to advise local Aboriginal governments on issues pertaining to development as well as monitoring any activity on the settlement lands such as resource development and research(15). Due to the incapacity of the CYFN and the 3 other Yukon First Nations to assume the financial burden of administering these regions, the Financial Transfer Agreement (FTA) was designed in which federal funding to the Yukon First Nations would be negotiated every five years. The goal of the FTA was to provide funding for services and programs in the Aboriginal regions while at the same time ensuring taxation levels remained similar to those of the rest of Canada. Another program developed to aide in the generation of revenue for the Yukon First Nations was The Programs and Services Transfer Agreements (PSTA) established between the Yukon First Nations and the YTG, in which the YTG would transfer the originally allotted funding to administering services and programs on Aboriginal lands to the Yukon First Nations. The Yukon First Nations, also, are allowed to tax its citizens and property(16); in support of this measure, the YTG has reduced territorial taxes levied in these areas to avoid double taxation(17). Though final land claims agreements are still underway, in theory the Yukon First Nations has acquired significant authority and revenue generation capabilities to govern themselves, their lands and resources.

\section{Contemporary Challenges Facing the YTG and the Yukon First Nations}

Overall, the YTG has developed the institutions, technical and managerial expertise needed for administrating former areas of jurisdictions controlled by DIAND. The creation of 'mirror legislation' by the YTG with respect to natural resources such as The Environmental Assessment Act and the Territorial Lands Act have entrenched preexisting federal legislation, creating a smooth transition from Ottawa to Whitehorse(18). At the 
same time, upon the completion of the Devolution Transfer Agreement (DTA), former DIAND bureaucrats working in the Yukon were reassigned to the YTG, providing the administrative expertise to assist in the transfer of federal responsibilities(19). The recent process of devolution, entrenched in the amended Yukon Act (2002), therefore was not a radical shift in policy orientation or institutional organization but mostly a transfer of similar legislation and staff from the federal government to the YTG. Due to these factors, it can be argued that the speed of the devolution process is a function of the YTG capacity to assume these new responsibilities in a bureaucratic framework similar to that of the federal government; Ottawa believes that Whitehorse has the ability to administer previous federal areas of jurisdictions in a manner which will be sustainable and stable, increasingly relying less federal involvement.

Though institutionally the YTG has the capacity to assume greater responsibilities, revenue generation is the major obstacle for continued devolution. Though short term economic forecasts predict a steady growth in revenue(20), the Yukon's economy is largely based on primary industries, such as minerals, which are vulnerable to world markets. For example, whereas Canada's GDP throughout the early to mid 1990s was growing at a slow but steady rate, the Yukon GDP in 1995 was 10\% lower than its 1992 levels(21). The level of volatility in the economy has a direct affect on population demographics. For example, The Yukon population decreased by 6.8\% between 1996 and 2001; the cause of the decline was attributed to the closing of the Mayo mine and a general lack of job opportunities due to weak investment by resource companies in the region(22). Revenue generation, therefore, funding new areas of territorial jurisdictions may become an issue with respect to personal income and property taxes. With a history of unstable population growth, the YTG may be forced to increase business taxes which may stifle investment. The impact of Aboriginal taxation, also, on the revenue capabilities of the YTG is still as of yet unknown.

Whereas the YTG has largely developed the institutional capacity to absorb new responsibilities as a result of the DTA, the Yukon First Nations face a number of challenges which are inhibiting the devolution process from moving forward. Specifically, the lack of indigenous technical expertise with respect to the management needed for self-rule and their relationship with the YTG are the two main obstacles. Generally, the Yukon First Nations have a strong political culture which supports selfrule. For example, in their charter the CYFN see themselves as one of the three levels of government in Canada, working towards the "entrenchment of the inherent right of selfgovernment”(23). Though there exists a mature level of civic development, institutional development concerns are limiting the abilities of the Yukon First Nations to effectively manage their settled lands.

According to the 2001 Census of Canada, 6,540 people in the Yukon Territory identified themselves as being a member of the Aboriginal community, representing $22.9 \%$ of the total Yukon population (stated as 28,674). Forty-eight percent $(3,150)$ of those of Yukon Aboriginal identity resided in Whitehorse with the other $52 \%$ living in various small communities, ranging from 45-1,000 inhabitants. The three largest communities in which 
Aboriginals comprise over $50 \%$ of the population are Carmacks (pop. 430), Mayo (pop. 365) and Ross River (pop.335) (24). Due to the small numbers of Yukon Aboriginals inhabiting their settled lands, therefore, there exist major problems over Aboriginal administration of these areas.

Though many Aboriginals have an in-depth knowledge of their lands, the managerial and planning skills needed for effective bureaucratic control of policy formulation and implementation is severely lacking. Of the 3,540 Yukon Aboriginals 25 years and older (comprising the bulk of the work force), only 230 have managerial occupations(25); these numbers, also, do not discriminate between the Aboriginals living on the settled lands and those in Whitehorse. With such a small population base, there is a constant need for skilled workers to staff First Nations Governments. High unemployment amongst Yukon Aboriginals (26.8\% according to the 2001 Census) combined with a labour force in which $33.5 \%$ of Aboriginals have less than a secondary school level education is further eroding the possibilities of developing a professional bureaucracy which is crucial for effective self-government. Though there are some signs suggesting an increased effort as of late by the YTG and Yukon First Nations to actively recruit and train specialists, particularly foresters, from amongst the Yukon Aboriginal communities, no real progress has come to fruition(26).

The perceived lack of internal capacity to assume the responsibilities within the selfgovernment agreements is causing reluctance on the part of the YTG to fully allow the Yukon First Nations authority over those jurisdictions. Further solidifying this philosophy is the entrenchment of existing federal programs via mirror legislation and the transfer of former federal employees to the YTG, which has forced the Yukon First Nations to work with similar institutions and bureaucratic mindsets which, generally, believe they are unfit to govern themselves. As Natcher and Davis comment “....First Nations now find themselves forced to deal with the same regulatory regime that was in place prior to administrative transfer and must continue to negotiate with the same individuals who opposed devolution from the outset”(27). Specifically, there exist significant differences concerning resource management. Whereas the YTG approaches these issues in a centralized, bureaucratic model, with particular emphasis on resource inventories, management programs and policy initiatives, the Yukon First Nations relies heavily on traditional codes of conduct for addressing such issues; a mindset which many non-First Nations, whom comprise an overwhelming majority of the YTG, have a difficult time understanding(28). The willingness, therefore, to transfer authority to Aboriginal Governments is lacking for the YTG believes that without these bureaucratic institutions and mindsets in place, effective governance is impossible.

Stemming from this conflicting relationship, funding problems are further inhibiting the ability of the Yukon First Nations to achieve self-rule. The largest concern amongst the Yukon First Nations is that they are not treated as an independent level of government in their negotiations with Whitehorse, which consistently interfere in their jurisdictions. For example, with respect to YOGA, the YTG agreed not to approve economic activities on First Nations lands without their approval and conduct talks over impact and beneficial 
agreements between the First Nations and developers. On many occasions, however, the YTG has taken opposing interests to those of the First Nations over development issues, creating a relationship of conflict, usually leading to the abandonment of developing deals simply because the Yukon First Nations feels they are not being treated as equals in negotiations. In some instances, the YTG has signed agreements with developers which in theory imply Fist Nations consent, but usually are in opposition to Aboriginal interests. Further deteriorating the relationship is the issue of the royalty regime funding formula, specifically the continual under-valuing of gold by the YTG which reduces the amount paid to the Yukon First Nations(29). Disagreements, also, between Ottawa and Whitehorse over compensation with regards to PSTAs has completely left the Yukon First Nations out of the discussions(30).

The lack of funding puts a significant strain on the Yukon First Nations measures for self-government. The absence of reliable financial support from either the YTG or the federal government inhibits development of the institutions and technical expertise needed to manage their settled lands. The funding that they do receive, also, is mostly in the form of conditional transfer payments, further limiting the ability to exercise their authority(31). This inability to institute resource management programs, in large part due to a lack of funding, serves as a justification of the YTG concerns over Aboriginal selfgovernment. The problem, however, is that it is the YTG which is disrupting the funding process, creating the conditions for the Yukon First Nations to fail in developing the institutions and procedures needed for self-rule.

\section{The Future of Devolution in the Yukon Territory}

\section{The YTG}

As has been demonstrated, the dual process of devolution occurring has been asymmetrical towards development, both civic and institutional, in relation to the YTG and the Yukon First Nations. Since the implementation of the DTA, with the transfer of former federal employees and the adoption of mirror legislation, there exists a functional bureaucracy which has given the YTG the capability to assume the responsibilities previously controlled by DIAND. Though through the amended Yukon Act there has been the implementation of a more autonomous territorial government, the prospects of constitutionally entrenching this status seem unlikely.

Referring to Dacks' model of political development and devolution, though the YTG has created the institutional capacity to assume new powers, civic development, one of the key components to constitutional development, is missing; the Yukon populace has no real desire to seek provincial status. Though recent public opinion data is lacking, in a November 2000 survey, only 29\% of the respondents believed devolution was a top governmental priority. In another poll conducted in October 2002, shortly after the implementation of the amended Yukon Act, 3\% of those asked believed devolution was the top governmental issue; this percentage decreased to $1.4 \%$ in February 2003(32). It seems political concerns are centered more on implementing the services inherited as a 
result of the devolution process and not on entrenching the growing autonomous nature of the YTG. There are, however, plans by the current Yukon Party Government to continue to process through consultations with Ottawa to eliminate the subordinate relationship that exists between the Yukon Commissioner and the Minister of DIAND, ensuring the YTG has the exclusive right to make decisions concerning territorial matters(33). Still, with a lack of popular support advocating provincehood, it appears measures to further devolve powers from Ottawa to Whitehorse will be through changes in federal statue.

As the amendment processes of Meech Lake and Charlottetown demonstrated, any future constitutional change process would most likely result in a reevaluation of major aspects of the document, beyond the entrenchment of the Yukon as a province. Since the failures of the Accords, 'mega-constitutional' measures have been undertaken in an effort by the federal government to address constitutional issues without reopening the Constitution. The possibility, therefore, that Ottawa would be willing to negotiate with Whitehorse over constitutional changes is quite low, especially considering the apparent apathetic mindset of the Yukon populace towards the issue. The ability, also, of the federal government to reclaim control over the Yukon's lucrative resources, although unlikely, may be a capability Ottawa wishes to maintain as a contingency in relation to potentially changing geo-political situations and concerns in the future.

\section{The Yukon First Nations}

Whereas civic development towards greater autonomy for the YTG is deficient in terms of the non-Aboriginal Yukon population, the process of devolution with respect to the Yukon First Nations is inhibited not by a lack of political support but by a lack of institutional development. The Yukon First Nations have a strong civic culture which sees itself as a legitimate level of government. YTG concerns, however, in relation to the development of the capacity to govern themselves has led to a conflicting relationship between Whitehorse and the Yukon First Nations over the devolution process. The key to further devolving of powers in support of Aboriginal self-rule, therefore, is the creation of a more constructive relationship between the Yukon First Nations and the YTG, resolving disagreements over interests in terms of resource management, planning and funding transfers. The Yukon First Nations are in a dependent relationship with Whitehorse for they comprise a small percent of the population, and as such have difficulty in aggregating political power to pressure the YTG to take action. The lack, also, of Aboriginals within the YTG is another factor mitigating the pressures for Aboriginal self-government from becoming a serious territorial political issue(34).

There are, however, signs that talks between the two may still bring greater authority to the Yukon First Nations. The present Yukon Party Government has asserted it will complete land claims negotiations with the goal of creating the conditions for the development of an institutional capacity to support First Nation governance(35). Consultations, also, are ongoing between the YTG, the Yukon First Nations and Ottawa, with the latest occurring in February 2008 discussing the findings of the nine-year report 
on the Yukon First Nation and Self Government Agreements. Key discussion points of these talks revolved around sustainable development issues, particularly the need for increased funding to support programs in the short term, aimed at establishing a competent Aboriginal bureaucracy capable of supporting self-rule(36). Ultimately, the prospects of Aboriginal self-rule depend on the level of institutional development, which is contingent on the ability to secure adequate financial and technical assistance for Whitehorse and Ottawa.

\section{$\underline{\text { Conclusion }}$}

Since the 1970s, there has been a steady process of devolution in the Yukon, culminating in the implementation of the amended Yukon Act (2002), giving the YTG a new range of powers primarily concerning resource management. The transition of these powers has been relatively smooth, with the YTG having the institutional infrastructure needed to administer these new jurisdictions. Presently, the process of devolution has largely been through changes in federal statue. The lack of a Yukon political culture (outside the Aboriginal population) pressuring for continued devolution, potentially with the end state of provincial status, combined with Ottawa's unwillingness to reopen the Constitution will most likely continue directing future devolution changes via federal statue.

At the same time, however, the process of devolution with respect to Aboriginal selfgovernment has been plagued with concerns over the lack of an institutional capacity to manage their own affairs. Though there exists a strong Aboriginal civic culture supporting self-rule, Whitehorse and Ottawa believe the political structures within these communities have not created the conditions for effective government. Issues over a lack of indigenous technical and managerial knowledge concerning resource management are the major obstacle inhibiting the process. The YTG in particular argues that this deficiency justifies the slow natured transition of power to the Aboriginal communities; these conditions, however, will most likely not evolve unless the YTG and Ottawa further invests the technical and financial assets needed to achieve effective Aboriginal selfgovernance. Ultimately, the process of devolution is contingent upon the acceptance of the YTG and the federal government of the Yukon Fist Nations as a legitimate level of government and, therefore, an increased willingness to develop strategies to address immediate concerns. The ability of the Yukon Fist Nations to aggregate their interests in a manner to affect in a significant way Yukon politics, pressuring the government and opposition into taking more action on the situation is critical for any hope of accelerating the process of devolution.

\section{Biography}

Adam MacDonald is a fourth year undergraduate student completing his BA in Political Science at the Royal Military College of Canada. Adam has held many leadership positions at RMC including the Cadet Wing Recreations Officer and the Cadet Squadron Leader. Adam, also, is a member of the RMC Strategic Liaison Council. 
Federalism-e: Volume 9

Adam's research interests include federalism, Canadian politics, strategic studies, and Asian politics. Next year, Adam will be pursuing his MA in Political Science at the University of Victoria. 
Footnotes

(1) The following description of Dackss model stems from Dacks, Gurtson, (1) An overview on devolution, Summer 1990, The Northern Review, no.5, pp. 11-15.

(2) Yukon Territory, Canadian Encyclopedia, http://www.thecanadianencyclopedia.com (accessed: 26 March 2008).

(3) Smyth, Steven, Constitutional development in the Yukon Territory: perspectives on the Jake Epp Letter, March 1999, Arctic, 52:1, pp. 71-74.

(4) Ibid, pp.75-76.

(5) Epp, Jake 1979. Letter to Commissioner Christensen, 9 Oct 1979 in Ibid, p.75.

(6) Smyth, pp. 76-77.

(7) The Yukon Act (2002), The Preamble, Department of Justice Canada www.justice.gc.ca (accessed: 28 Jan 2008).

(8) Ibid, Article 10.

(9) Irlbacher-Fox, Stephanie, and Mills, Stephen J. Devolution and Resource Revenue Sharing in the Canadian North: Achieving Fairness Across Generations (2007), Commissioned by the Walter and Duncan Gordon Foundation, www.gordonfin.org (accessed: 15 March 2008), p.5.

(10) Backgrounder: Northern Affairs Program Devolution Transfer Agreement, The Department of Indian Affairs and Northern Development (DIAND), www.ainc-inac.gc.ca (accessed: 28 Jan 2008)

(11) Throughout the paper the acronym CYFN will represent the 11 First Nations which are a part of the Council of Yukon First Nations. When Yukon First Nations is used, it implies the 11 groups of CYFN and the three other autonomous First Nations.

(12) Dacks, Gurtson, (2) Implementing First Nations Self-Government in Yukon: Lessons for Canada”, September 2004, Canadian Journal of Political Science, 37:3, 671694, p.675.

(13) Natcher, David C. and Davis, Susan (2007) Rethinking Devolution: Challenges for Aboriginal Resource Management in the Yukon Territory” Society \& Natural Resources, 20:3, 271-279. p.272.

(14) Irlbacher-Fox, Stephanie, and Mills, Stephen J, p.6. 
(15) Natcher, David C. and Davis, Susan, p.273.

(16) Under consultations with Ottawa, as well, certain Yukon Fist Nations can tax nonAboriginals inhabiting their area of jurisdictions. Dacks (2), P.276.

(17) Dacks, (2), pp.275-276.

(18) Natcher, David C. and Davis, Susan, p.276.

(19) Backgrounder: Northern Affairs Program Devolution Transfer Agreement, DIAND.

(20) 2008-2009 Projections, Yukon Department of Finance www.finance.gov.yk.ca (accessed: 25 March 2008).

(21) Grenon, Lee, Employment and industrial development in the North (1997), Perspectives, 18-27, www.statscan.ca (accessed: 15 March 2008), p.20.

(22) 2001 Census Aboriginal Population Profiles, StatisitcsCanada, www.statscan.ca (accessed: 15 March 2008).

(23) Constitution of the Council of Yukon First Nations, Article 2-Objectives (b), Council of Yukon First Nations, www.cyfn.ca (accessed: 28 Jan 2008).

(24) Aboriginal Data: 2001 Census, Yukon Bureau of Statistics, www.eco.gov.yk.ca (accessed: 28 Jan 2008).

(25) 2001 Census Aboriginal Population Profiles, StatisitcsCanada.

(26) Natcher, David C. and Davis, Susan, p.273.

(27) Ibid, p.277.

(28) For an example of traditional First Nations approaches to resource management see the DooLi case of the Northern Tutchone Council. Ibid, p.274.

(29) Irlbacher-Fox, Stephanie, and Mills, Stephen J, pp.10-15.

(30) Dacks, (2), p.682.

(31) Natcher, David C. and Davis, Susan, p.276.

(32) Yukon Public Opinion Surveys, Data Path Systems, www.datapathsystems.net (accessed: 17 March 2008). 
Federalism-e: Volume 9

(33) Building Yukons Future Together- A Clear Vision for a Bright Future The Yukon Party, www.yukonparty.ca (accessed: 15 March 2008), p.27.

(34) Dacks, (2), p.675.

(35) Building Yukons Future Together- A Clear Vision for a Bright Future The Yukon Party, p.26.

(36) Yukon First Nations and Yukon Government heading to Ottawa, Canada Newswire, 8 Feb 2008. 


\section{References}

1. “Aboriginal Data: 2001 Census”, Yukon Bureau of Statistics, www.eco.gov.yk.ca (accessed: 28 Jan 2008).

2. “Building Yukon's Future Together- A Clear Vision for a Bright Future”, The Yukon Party, www.yukonparty.ca(accessed: 15 March 2008).

3. "Constitution of the Council of Yukon First Nations", Council of Yukon First Nations, Dacks, Gurtson, “An overview on devolution”, Summer 1990, The Northern Review, no.5, 11-15.

4. “Implementing First Nations Self-Government in Yukon: Lessons for Canada”, September 2004, Canadian Journal of Political Science, 37:3, 671-694.

5. Grenon, Lee, "Employment and industrial development in the North" (1997), Perspectives, 18-27, http://www.statscan.ca (accessed: 15 March 2008).

6. Irlbacher-Fox, Stephanie, and Mills, Stephen J. "Devolution and Resource Revenue Sharing in the Canadian North: Achieving Fairness Across Generations" (2007), commissioned by the Walter and Duncan Gordon Foundation, www.gordonfin.org (accessed: 15 March 2008).

7. Natcher, David C. and Davis, Susan (2007) "Rethinking Devolution: Challenges for Aboriginal Resource Management in the Yukon Territory” Society \& Natural Resources, 20:3, 271-279.

8. “Back Grounder: Northern Affairs Program Devolution Transfer Agreement”, Department of Indian Affairs And Northern Development, www.ainc-inac.gc.ca (accessed: 28 Jan 2008).

9. “2008-2009 Projections”, Yukon Department of Finance, finance.gov.yk.ca (accessed: 25 March 2008).

10. Smyth, Steven, “Constitutional development in the Yukon Territory: perspectives on the Jake Epp Letter”, March 1999, Arctic, 52:1, 71-79.

11. The Yukon Act (2002), Department of Justice Canada, www.justice.gc.ca (accessed: 28 Jan 2008).

12. “2001 Census Aboriginal Population Profiles”, StatisitcsCanada, www.statscan.ca (accessed: 15 March 2008).

13. "Yukon First Nations and Yukon Government delegates heading to Ottawa", 8 Feb 2008,Canada NewsWire. 
Federalism-e: Volume 9

14. "Yukon Public Opinion Surveys", Datapath systems, www.datapathsystems.ca (accessed: 17 March 2008).

15. "Yukon Territory”, Canadian Encyclopedia, www.canadianencycloepdia.com (accessed: 26 March 2008). 